Yu. F. Romaniuk, Cand. Sc. (Tech.), Assoc. Prof., orcid.org/0000-0002-5765-2961,

O. V.Solomchak, Cand. Sc. (Tech.), Assoc. Prof., orcid.org/0000-0003-1011-1014,

P.M. Nykolyn, orcid.org/0000-0003-1453-8445,

U. M. Nykolyn, Cand. Sc. (Tech.), orcid.org/0000-0001-9111-1280
Ivano-Frankivsk National Technical University of Oil and Gas, Ivano-Frankivsk, Ukraine, e-mail: ulanda@gmail.com

\title{
PECULIARITIES OF ELECTRIC POWER LOSS CALCULATION IN POWER SUPPLY SYSTEMS WITH COMPENSATING DEVICES
}

Purpose. Improvement of calculation accuracy of electric power losses in power supply systems of the oil and gas complex with reactive power compensation by applying the method of graphical integration of power losses and the choice of optimum capacity of compensating devices.

Methodology. The improved method for determining the time of the largest losses, taking into account the largest power losses separately from the active and reactive power transmission, has allowed increasing the accuracy of the energy loss determination. The method for determining the optimum capacity of compensating devices is proposed.

Findings. The necessity of taking into account the form of charts of active and reactive capacities and the power of compensating devices during calculation of electric power losses in power supply systems is substantiated. It has been shown that the efficiency of reactive power compensation in order to reduce the power losses significantly decreases with high values of the power factor.

Originality. The method of unregulated compensating devices optimum power calculation is proposed, provided the minimum power losses in the power supply system. The method of electric power loss calculation in power supply systems with compensating devices is improved by means of separate account of active and reactive power components during determination of the time of the largest losses, which allows increasing accuracy and reducing errors of calculations. The structure of the determination method of energy losses in the network is synthesized, which, unlike the existing one, allows taking into account the influence of the difference in the maxima of active and reactive load on the accuracy of calculations and optimizing the power of compensating devices.

Practical value. Improved accuracy of calculation of electricity losses. Selection of optimal power of unregulated compensating devices, which corresponds to the minimum power losses in the power supply.

Keywords: energy losses, compensating device, compensation efficiency

Introduction. The annual electricity losses in the energy systems of the European Union make up an average of 2 to $12 \%$, according to the ERGEG program of reduction of losses by network operators [1]. At the same time, the European Energy Efficiency Directive requires all Member States to assess the energy efficiency potential and specify measures to improve it. Reducing losses is a real challenge for all European countries.

One of the most effective technical measures to reduce electricity losses in electric networks of oil and gas complexes (NGCs) is the compensation of reactive power load [2, 3], which allows reducing electricity losses and charges for its payment and improving the quality of electric power. Methods of calculation of electric power losses when choosing the economically feasible power of compensating devices (CD) should provide acceptable accuracy for calculations in the case of availability of relevant information on the load, which in most cases is characterized by limited completeness and probability. Under the conditions of operation, electricity losses are mostly determined by the approximate method during the time of the largest losses $\tau$ [4]; therefore, additional questions arise regarding the improvement of the accuracy of the calculation of losses and the correct choice of power of the CD.

Literature review. A large number of scientific papers are devoted to issues of compensation of reactive power load of power supply systems, improved means of compensation and methods for selecting the optimal capacity of compensating devices, including taking into account the payment for the flow of electricity between the transmission company and its customers.

In $[5,6]$, the method for choosing the type and optimal reactive power of sources of compensation of reactive load of

C Romaniuk Yu. F., Solomchak O. V., Nykolyn P. M., Nykolyn U. M., 2019 consumers is considered on the criterion of minimum discounted costs, which include expenses for generation and transfer of reactive power to consumers, capital investments for installation of compensating devices and expenses for their operation.

In [7] the method of complex estimation of efficiency of installation of sources of reactive power in electric networks has been developed. The efficiency indicator was obtained by combining the method for assessing the quality of functioning of the electricity grids on the basis of Markov networks and the method of interval analysis of electricity losses.

The paper [8] investigated the effect of compensation of reactive power on the parameters of the regime and the stability of the electric system, established allowable levels of compensation of reactive power and their influence on the stability of load nodes. The technical and economic efficiency of the degree of compensation of reactive power on the parameters of the regime of the electric system according to the "deep input" scheme is established, taking into account the daily unevenness of the load.

In [9] the problem of optimization of reactive energy flows by distribution electric networks is considered on the basis of a complex criterion, which takes into account expenses for the operation of reactive power sources (RPS), losses and the quality of electric power. The optimality conditions for construction of a distributed control system with automatic local control are proposed.

The works [10,11] consider the increase in the efficiency of the use of compensating installations by developing and implementing a system for the introduction of reactive power compensation systems in the distribution electrical grids on the basis of their decomposition.

The monograph [12] examines the methods for determining the losses of active electricity from the flow of reactive power in electric networks of consumers and power supply 
companies, which allows forming conditions for optimal compensation of reactive power.

In [13], the methodology and implementation of a new dynamic analysis for estimating power losses in distribution networks with distributed sources was developed and used. The use of new inverter technologies with reactive power regulation allows for the integration of higher installed generation power capacities, without significant additional network enhancements.

To calculate losses, use daily or annual load schedules in duration $[14,15]$. The annual load schedule $S(t)$ can be obtained on the basis of daily charts of active $P(t)$ and reactive $Q(t)$ loads. In the absence of the graph $Q(t)$, it is assumed that the reactive power of the load varies as actively and when determining the full power use the average value of the coefficient of power $\cos \varphi_{\text {aver }}$, which is conditionally accepted constant during the year.

The method of graphical integration of power losses is characterized by high accuracy, but is very labor intensive [4]. In order to simplify the calculations, in practice, preference is given to daily charts for characteristic periods of time. To do this, they set the number of characteristic days within the billing period. However, as studies [2, 8] have shown, this method does not provide the necessary precision due to the continuous influence on the power system of regular and irregular disturbances, since the scheme, regimes and energy losses do not remain stable during the calculation period.

Charts of electric loads $P(t), Q(t)$ are not always given, so when determining energy losses they often use approximate methods of calculation. One of the most common approximated methods of calculation is the calculation of losses during the time of the largest losses $\tau$, during which the maximum load of $S_{m}$ energy losses would be the same as for the variable load during the year. However, in most cases, $\tau$ takes into account a constant value that adds an additional error to the calculation. In case of compensation of the reactive load, the time of the largest losses $\tau$, which depends on the area of the quadratic load plot, varies depending on the power of the $\mathrm{CD}$. Therefore, this dependence must be taken into account when calculating the electricity losses and choosing the optimal power of the CD.

Unsolved aspects of the problem. The choice of economically feasible power of the $\mathrm{CD}$ in the electricity supply systems of the NGC is made on the basis of their variant comparison taking into account the cost of electricity losses, capital investments for the installation of $\mathrm{CD}$ and their operation. In addition, account should be taken of the charge for the flow of reactive electricity between the transmission company and its customers [16]. When determining the energy losses, the dependence of the time of the largest losses on the change in the schedule of reactive loads is not taken into account, which adds an additional error to their calculation and the choice of optimal power of the CD.

Purpose. The purpose of the work is to assess the accuracy and further improve the method for calculating the losses of electricity over time of the largest losses and the choice of optimal power of unregulated CD in the electricity supply systems of the NGC.

To solve the problem, the following tasks are formulated:

- analysis of methods for calculation of electric power losses according to the schedules of electric loads;

- estimation of errors of calculation of electric power losses in time of the largest losses depending on the power of the CD;

- analysis of the time dependence of the largest losses on active, reactive and total capacities at different values of the power of the $\mathrm{CD}$;

- choice of optimum power of the CD with allowance for restrictions;

- estimation of the efficiency of compensation of reactive load power.

Results. If the load of the electric network varies over time, then total energy losses during the estimated period can be defined as the sum of energy losses under different $\mathrm{Si}$ modes of operation as

$$
\Delta W=\sum_{i=1}^{n} \Delta P_{i} \Delta t_{i}=\frac{R}{U^{2}} \sum_{i=1}^{n} S_{i}^{2} \Delta t_{i},
$$

where $\Delta P_{i}$ is power loss at time interval $\Delta t_{i} ; R$ is active resistance of the electric network; $U$ is average voltage at the load node; $S_{i}$ is load power, attributed to the time interval $\Delta t_{i} ; n$ is the number of time intervals of the schedule of electrical loads.

Since the voltage levels at the load nodes are unknown in most cases and vary in small limits, then during the calculation of electricity losses we take $U=U_{\text {nom }}$.

The annual losses of active power in the line over time are the largest losses calculated by

$$
\Delta W=\frac{S_{m}^{2}}{U_{n o m}^{2}} R \tau=\frac{P_{m}^{2}+Q_{m}^{2}}{U_{n o m}^{2}} R \tau=\Delta P_{m} \tau
$$

where $\Delta P_{\mathrm{m}}$ is loss of active power in the mode of maximum loads.

The time of the largest losses $\tau$ is determined by calculation for characteristic charts of the load of consumers of various branches from the expression

$$
\tau=\frac{\int_{0}^{8760} S^{2}(t) d t}{S_{m}^{2}},
$$

and refer to the reference, depending on the time of use of the largest load $T_{m}$ and the average power factor. The approximate value of $\tau$ can also be determined by the empirical formula

$$
\tau=\left(0.124+\frac{T_{m}}{10000}\right)^{2} 8760 .
$$

In order to take into account the configuration of the load schedules, the actual values of power factors, the possible inconsistency of the maximum active and reactive power in time within the time period of the day and year, it is possible to calculate the losses of electricity from the active and reactive power flows separately. For this, according to the schedules of the duration of active and reactive loads, we calculate the time of the greatest losses for the $\tau_{a}$ active and $\tau_{r}$ reactive power

$$
\begin{gathered}
\tau_{a}=\frac{\int_{0}^{8760} P^{2}(t) d t}{P_{m}^{2}} ; \\
\tau_{r}=\frac{\int_{0}^{8760} Q^{2}(t) d t}{Q_{m}^{2}},
\end{gathered}
$$

after which we determine the electricity losses as

$$
\Delta W=\frac{P_{m}^{2} \tau_{a}+Q_{m}^{2} \tau_{r}}{U_{\text {nom }}^{2}} R,
$$

or for loads given by currents,

$$
\Delta W=3 I_{m}^{2} R\left(\tau_{a} \cos ^{2} \varphi_{m}+\tau_{r} \sin ^{2} \varphi_{m}\right) .
$$

Under conditions of operation of electric networks, the loss of electricity is mostly determined by the approximate method during the time of the largest loss $\tau$ by (2), while the time of using the largest load $T_{m}$ is calculated by the annual lifetime of active loads

$$
T_{m}=\frac{\sum_{i}^{n} P_{i} \Delta t_{i}}{P_{m}}
$$


or the annual consumption of active electricity $W P$ as

$$
T_{m}=\frac{W P}{P_{m}}
$$

In case of compensation of a reactive load the time of the largest losses can be calculated as

$$
\tau=\frac{\sum_{i=1}^{n} S_{i}^{2} \Delta t_{i}}{S_{m}^{2}}+\frac{\sum_{i=1}^{n}\left(P_{i}^{2}+\left(Q_{i}-Q_{k}\right)^{2}\right) \Delta t_{i}}{P_{s}^{2}+\left(Q_{s}-Q_{k}\right)^{2}},
$$

where $P_{S}, Q_{S}$ are active and reactive powers that correspond to the maximum value of full load power $S_{m} ; Q_{k}$ is power of compensating devices.

Explanation of scientific results. Let us calculate annual losses of electricity over time, the largest losses in the line voltage of $10 \mathrm{kV}$ and active resistance $R=5 \mathrm{Ohms}$ for the daily charts of active and reactive loads given in Fig. 1 in the assumption of their uniform form throughout the year, and analyze the dependence $\tau=f\left(Q_{k}\right)$ for different variants of reactive power compensation.

For a given schedule of active loads, the annual consumption of active electricity is $(\mathrm{kWh})$

$$
W P=(1 \cdot 8+1.5 \cdot 8+0.8 \cdot 8) \cdot 365=9636,
$$

with the time of using the maximum load (h)

$$
T_{m}=\frac{W P}{D_{m}}=\frac{9636}{1.5}=6424 .
$$
(2), h

Calculate the time of the largest losses under the empirical

$$
\tau=\left(0.124+\frac{6424}{10000}\right)^{2} 8760=5145
$$

Determine the loss of active power in the mode of maximum load in the absence of compensation, MW

$$
\Delta P_{m}=\frac{S_{m}^{2}}{U_{m}^{2}} R=\frac{1.5^{2}+0.6^{2}}{10^{2}} 5=0.131 .
$$

Annual losses of active electricity will approximate, MWh

$$
\Delta W_{\text {appr }}=\Delta P_{m} \tau=0.131 \cdot 5145=671 .
$$

Determine the actual time of the largest losses under the quadratic full load graph (h)

$$
\tau_{s}=\frac{365 \sum_{i=1}^{n} S_{i}^{2} \Delta t_{i}}{S_{m}^{2}}=\frac{365 \sum_{i=1}^{n}\left(P_{i}^{2}+Q_{i}^{2}\right) \Delta t_{i}}{S_{m}^{2}} ;
$$

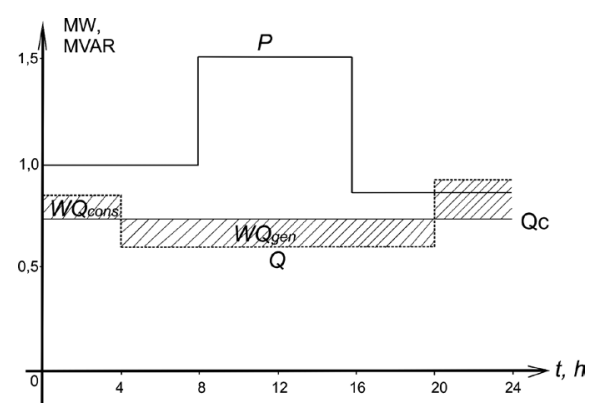

Fig. 1. Daily load schedules before and after reactive power compensation

$$
\begin{gathered}
\tau_{s}=\left(\frac{\left(1^{2}+0.8^{2}\right) \cdot 4+\left(1^{2}+0.6^{2}\right) \cdot 4+\left(1.5^{2}+0.6^{2}\right) \cdot 8}{1.5^{2}+0.6^{2}}+\right. \\
\left.+\frac{\left(0.8^{2}+0.6^{2}\right) \cdot 4+\left(0.8^{2}+0.9^{2}\right) \cdot 4}{1.5^{2}+0.6^{2}}\right) \cdot 365=5969 .
\end{gathered}
$$

Actual electricity losses for the year will amount to, MWh

$$
\Delta W=\Delta P_{m} \tau_{s}=0.131 \cdot 5969=779 .
$$

A similar result can be obtained directly by the method of graphical integration of power losses by (1).

The error of determining the energy losses by the approximate calculation method is (\%)

$$
\delta=\frac{671-779}{779}=-13.8,
$$

which is significant.

Let us analyze the influence of the form of the active load schedule on the error of the approximate method of calculation of electric power losses Approximately $\tau$ is determined by the empirical formula (2) during the use of the largest load $T_{m}$, whose magnitude depends on the form of the active load schedule. In order to analyze the dependence of the error of the approximate method of calculating the electricity losses, a series of calculations for various values of the maximum active load was performed. At the same time, the active loading in other periods of time and the schedule of reactive loading remained constant. The results of calculations are given in Table 1 .

According to the calculations, we see that in the case of a decrease in the maximum load of $P_{m}$ from 1.5 to $1.1 \mathrm{MW}$, the magnitude of $T_{m}$ increases from 6424 to 7698 hours due to the equalization of the active load schedule, while according to (2), the approximate value of $\tau_{\text {appr }}$ will increase from 5145 to 6998 hours, and the approximate value of electricity losses in the absence of compensation will be (MWh)

$$
\Delta W_{a p p r}=\Delta P_{m} \tau=\frac{1.1^{2}+0.6^{2}}{10^{2}} \cdot 5 \cdot 6998=0.09 \cdot 6998=573 .
$$

Time of maximum losses is determined by the quadratic load schedule $\tau_{s}=7647$ hours, with the actual value of electricity losses, MWh

$$
\Delta W=\Delta P_{m} \tau=0.09 \cdot 7647=627,
$$

and the error of calculation of losses will decrease and make up $(\%)$

$$
\delta=\frac{573-627}{627} \cdot 100=-8.5 \text {. }
$$

Table 1

Results of calculation of electric power losses at different values of maximum active loading

\begin{tabular}{|c|c|c|c|c|c|c|}
\hline $\begin{array}{c}P_{m}, \\
\mathrm{~kW}\end{array}$ & $\begin{array}{c}T_{\mathrm{m}}, \\
\text { hours }\end{array}$ & $\begin{array}{c}\tau_{\text {appr }}, \\
\text { hours }\end{array}$ & $\begin{array}{c}\tau_{s}, \\
\text { hours }\end{array}$ & $\begin{array}{c}\Delta W_{\text {appr, }}, \\
\mathrm{kWh}\end{array}$ & $\begin{array}{c}\Delta W_{s}, \\
\mathrm{kWh}\end{array}$ & $\delta, \%$ \\
\hline 1 & 8176 & 7767 & 7273 & 637 & 596 & 6.8 \\
\hline 1.1 & 7698 & 6998 & 7647 & 573 & 627 & -8.5 \\
\hline 1.2 & 7300 & 6389 & 7341 & 575 & 660 & -13.0 \\
\hline 1.3 & 6963 & 5895 & 6802 & 604 & 697 & -13.3 \\
\hline 1.4 & 6674 & 5487 & 6305 & 636 & 737 & -13.7 \\
\hline 1.5 & 6424 & 5145 & 5968 & 671 & 778 & -13.8 \\
\hline 1.6 & 6205 & 4855 & 5645 & 708 & 824 & -14.1 \\
\hline
\end{tabular}


In case of a decrease in the maximum load to $1 \mathrm{MW}$, the error of calculation of electricity losses becomes positive and will amount to $\delta=6.8 \%$.

As we see from the calculations, the error of calculation of electric power losses over time of the largest loss depends on the form of the schedule of active loads. In case of an increase in the unevenness of the graph (form factor), the error from the positive gradually changes to negative and increases in absolute magnitude.

Let us analyze the effect of compensation of the reactive load on the error of the approximate method of calculation of electric power losses. Let us consider for the given example the variant of compensation of reactive loading power by unregulated CD by power $Q_{C}=0.5 \mathrm{MVAR}$. At the same time, the consumption of active energy will not change, and the usage of reactive energy will decrease.

We calculate the annual electricity losses, taking into account the compensation of reactive power

$$
\begin{gathered}
\tau_{s}=\frac{\sum_{i=1}^{n}\left(P_{i}^{2}+\left(Q_{i}-Q_{C}\right)^{2}\right) \cdot \Delta t_{i}}{P_{i}^{2}+\left(Q_{i}-Q_{C}\right)^{2}}= \\
=\frac{\left(\left(1^{2}+(0.8-0.5)^{2}\right) \cdot 4+\left(1^{2}+(0.6-0.5)^{2}\right) \cdot 4\right.}{1.5^{2}+(0.6-0.5)^{2}}+ \\
+\frac{\left(1.5^{2}+(0.6-0.5)^{2}\right) \cdot 8+\left(0.8^{2}+(0.6-0.5)^{2}\right) \cdot 4}{1.5^{2}+(0.6-0.5)^{2}}+ \\
+\frac{\left(0.8^{2}+(0.9-0.5)^{2}\right) \cdot 4}{1.5^{2}+(0.6-0.5)^{2} \cdot 365=5213 ;} \\
\Delta P_{m}=\frac{S_{m}^{2}}{U_{n o m}^{2}} R=\frac{1.5^{2}+(0.6-0.5)^{2}}{10^{2}} 5=0.113 ; \\
\Delta W=\Delta P_{m} \tau=0.113 \cdot 5213=589,
\end{gathered}
$$

where $\tau_{S}$ in hours; $\Delta P_{m}$ in MW; $\Delta W$ in MWh.

Let us determine the loss of electricity from the transmission of active and reactive power separately

$$
\begin{gathered}
\Delta W_{a}=\frac{P_{m}^{2}}{U_{n o m}^{2}} R=\Delta P_{a . m} \tau_{a} ; \\
\Delta W_{r}=\frac{\left(Q_{m}-Q_{C}\right)}{U_{n o m}^{2}} R=\Delta P_{r . m} \tau_{r},
\end{gathered}
$$

where

$$
\begin{gathered}
\Delta P_{a . m}=\frac{1.5^{2}}{10^{2}} 5=0.113 ; \\
\Delta P_{r . m}=\frac{(0.9-0.5)^{2}}{10^{2}} 5=0.008 ; \\
\tau_{a}=\frac{\left(1^{2} \cdot 8+1.5^{2} \cdot 8+0.8^{2} \cdot 8\right) \cdot 365}{1.5^{2}}=5048 ; \\
\tau_{r}=\frac{(0.8-0.5)^{2} \cdot 4+(0.6-0.5)^{2} \cdot 16+(0.9-0.5)^{2} \cdot 4}{(0.9-0.5)^{2}} \cdot 365=2644 ; \\
\Delta W_{a}=0.113 \cdot 5048=568 ; \\
\Delta W_{r}=0.008 \cdot 2644=21 ; \\
\Delta W=568+21=589 ;
\end{gathered}
$$

that is, the results of calculation of electric power losses coincide with the previous calculation; $\Delta P_{a . m}, \Delta P_{r . m}$ in MW; $\tau_{a}, \tau_{r}$ in hours; $\Delta W_{a}, \Delta W_{r}, \Delta W$ in MWh.
If we do not take into account the time dependence of the greatest losses on the change in the full load graph and set $\tau$ a constant value, then the loss of active electricity per year will be (MWh)

$$
\Delta W_{\text {appr }}=0.113 \cdot 5146=581 .
$$

The error of calculating the power losses over time with the largest losses, determined by (2), will be (\%)

$$
\delta=\frac{581-589}{589} \cdot 100=-1.4,
$$

and its value in comparison with the absence of compensation decreases as a result of the reduction of the reactive component of the load power and its effect on the value of full power.

The analysis showed that the time of the largest losses $\tau$ depends on the configuration of the active and reactive load schedules, their duration, and the power of the CD. In the same configuration of graphs and the same ratio between active and reactive load, the time of the greatest losses from the transmission of active, reactive and full power is the same, since load power factors are unchanged throughout the calculation period

$$
\tau=\frac{\sum_{i=1}^{n} S_{i}^{2} \Delta t_{i}}{S_{m}^{2}}=\tau_{\dot{a}}=\tau_{r} .
$$

In case of reactive load power compensation, the configuration of the schedule of reactive loads changes, so the time of the greatest losses from the transfer of reactive and complete capacities is changing. At the same time, the value of maximum power losses changes.

Thus, the magnitude of the error is influenced by the change in the configuration of the schedule of reactive loads. In order to analyze the time dependence of the largest losses from the power of compensating devices, a series of calculations for various compensation options was carried out. The results of the calculations are presented in Tables 2, 3. Dependency graphs $\tau=f\left(Q_{C}\right)$ and $\Delta W_{P}=f\left(Q_{C}\right)$ for given loading schedules are shown in Figs. 2, 3.

The calculation results show that the error in determining the energy losses by the approximate method can be significant and depends on the configuration of the active and reactive load schedules and the power of compensating devices $Q_{C}$. In case of overcompensation, it becomes positive, that is,

Table 2

Results of calculation of electric power losses at different power compensation values $Q_{C}$

\begin{tabular}{|c|c|c|c|c|c|}
\hline $\begin{array}{c}Q_{C}, \\
\text { kVAR }\end{array}$ & $\tau$, hours & $\Delta P_{m}, \mathrm{~kW}$ & $\begin{array}{c}\Delta W_{\text {appr, }} \\
\mathrm{MWh}\end{array}$ & $\begin{array}{c}\Delta W, \\
\mathrm{MWh}\end{array}$ & $\delta, \%$ \\
\hline 0 & 5969 & 0.131 & 671.4 & 778.9 & -13.8 \\
\hline 0.1 & 5787 & 0.125 & 643.1 & 723.4 & -11.1 \\
\hline 0.2 & 5616 & 0.121 & 620.0 & 676.7 & -8.4 \\
\hline 0.3 & 5459 & 0.117 & 602.0 & 638.8 & -5.8 \\
\hline 0.4 & 5324 & 0.115 & 589.1 & 609.6 & -3.4 \\
\hline 0.5 & 5213 & 0.113 & 581.4 & 589.1 & -1.3 \\
\hline 0.6 & 5133 & 0.113 & 578.8 & 577.4 & 0.2 \\
\hline 0.683 & 5090 & 0.113 & 580.6 & 574.4 & 1.1 \\
\hline 0.7 & 5084 & 0.113 & 581.4 & 574.5 & 1.2 \\
\hline 0.8 & 5069 & 0.115 & 589.1 & 580.4 & 1.5 \\
\hline 0.9 & 5085 & 0.117 & 602.0 & 595.0 & 1.2 \\
\hline 1 & 5131 & 0.121 & 620.0 & 6183 & 0.3 \\
\hline
\end{tabular}


Table 3

Results of calculation of electric power losses from active and reactive power transmission

\begin{tabular}{|c|c|c|c|c|c|c|c|}
\hline $\begin{array}{c}Q_{C}, \\
\text { kVAR }\end{array}$ & $\begin{array}{c}\tau_{a}, \\
\text { hours }\end{array}$ & $\begin{array}{c}\tau_{r}, \\
\text { hours }\end{array}$ & $\begin{array}{c}\Delta P_{a . m}, \\
\mathrm{~kW}\end{array}$ & $\begin{array}{c}\Delta P_{\text {r.m }}, \\
\mathrm{kW}\end{array}$ & $\begin{array}{c}\Delta W_{a}, \\
\mathrm{MWh}\end{array}$ & $\begin{array}{c}\Delta W_{r}, \\
\mathrm{MWh}\end{array}$ & $\begin{array}{c}\Delta W, \\
\mathrm{MWh}\end{array}$ \\
\hline 0 & 5048 & 5209 & 0.113 & 0.041 & 567.9 & 211.0 & 778.9 \\
\hline 0.1 & 5048 & 4859 & 0.113 & 0.032 & 567.9 & 155.5 & 723.4 \\
\hline 0.2 & 5048 & 4440 & 0.113 & 0.025 & 567.9 & 108.8 & 676.7 \\
\hline 0.3 & 5048 & 3934 & 0.113 & 0.018 & 567.9 & 70.8 & 638.8 \\
\hline 0.4 & 5048 & 3329 & 0.113 & 0.013 & 567.9 & 41.6 & 609.6 \\
\hline 0.5 & 5048 & 2646 & 0.113 & 0.008 & 567.9 & 21.2 & 589.1 \\
\hline 0.6 & 5048 & 2109 & 0.113 & 0.005 & 567.9 & 9.5 & 577.4 \\
\hline 0.683 & 5048 & 2746 & 0.113 & 0.002 & 567.9 & 6.4 & 574.4 \\
\hline 0.7 & 5048 & 3285 & 0.113 & 0.002 & 567.9 & 6.6 & 574.5 \\
\hline 0.8 & 5048 & 6205 & 0.113 & 0.002 & 567.9 & 12.4 & 580.4 \\
\hline 0.9 & 5048 & 6002 & 0.113 & 0.005 & 567.9 & 27.0 & 595.0 \\
\hline 1 & 5048 & 6296 & 0.113 & 0.008 & 567.9 & 50.4 & 618.3 \\
\hline
\end{tabular}

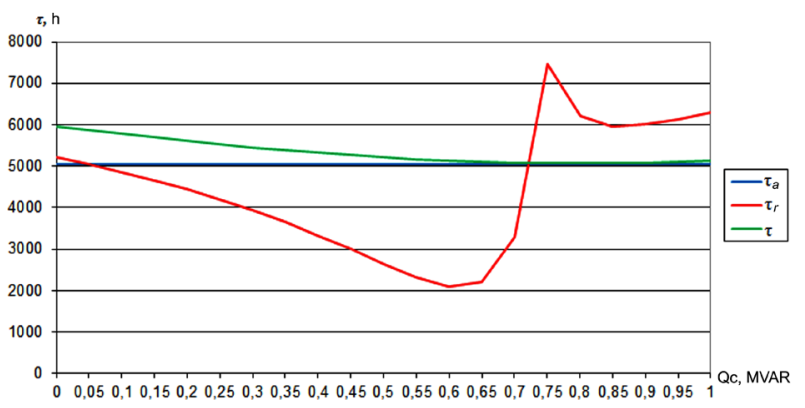

Fig. 2. Graphs of dependence of the maximum loss time on the power of compensatio

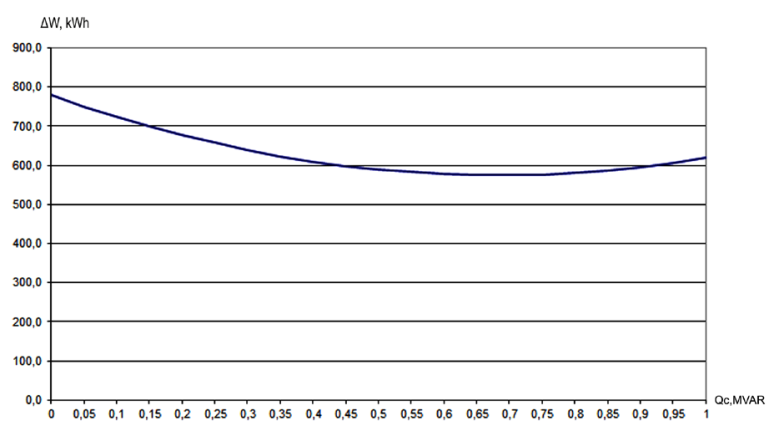

Fig. 3. Graph of dependence of electric power losses on compensation powe

losses calculated by the approximate method will be greater than actual losses (Table. 2).

Choosing the optimum power of compensating devices. Partial optimization criterion is the minimum of total electric power losses in the electric network from the transfer of active and reactive power. As calculations have shown, in the case of using unregulated $\mathrm{CD}$, the minimum power losses correspond to the condition when the amount of consumed reactive electricity during the calculation period is equal to the amount of electricity generated in the system as a result of overcompensation

$$
W Q_{\text {cons }}=W Q_{\text {gen }} .
$$

Total electricity losses consist of losses from the transmission of active and reactive power

$$
\Delta W=\Delta W_{a}+\Delta W_{r} .
$$

In case of fulfillment of condition (3), the component of losses $\Delta W_{a}$ remains constant, while losses $\Delta W_{r}$ from the transfer of reactive power, and hence total power losses, reach the minimum values due to the alignment of the loading schedule and the reduction of the maximum load of the line.

The optimum power of unregulated $\mathrm{CD}$ can be determined from condition (3), equalizing the total area of the reactive load schedule to zero

$$
F=\sum_{i=1}^{n}\left(Q_{i}-Q_{C}\right) \Delta t=W Q_{\text {cons }}-Q_{C} T=0,
$$

where $Q_{i}$ is reactive load power at the second interval of the graph; $W Q_{\text {cons }}$ is the amount of consumed reactive energy; $Q_{C}$ is power unregulated $\mathrm{CD}$; $T$ is the duration of the billing period.

According to (4)

$$
Q_{C}=Q_{\text {aver }}=\frac{\sum_{i=1}^{n} Q_{i} \Delta t}{T},
$$

that is, the optimum power of the $\mathrm{CD}$ is equal to the average reactive power of the load during the estimated period.

For the annual schedule of reactive loads

$$
Q_{C}=\frac{W Q_{\text {cons }}}{8760}=\frac{365 \sum_{i=1}^{n} Q_{i} \Delta t}{8760},
$$

where $W Q_{\text {cons }}$ is the annual amount of consumed reactive energy, which in the conditions of operation can be determined by the data of accounting devices.

For the reactive load graph given in Fig. 1, annual electricity consumption is (MVARh)

$$
W Q_{\text {cons }}=(0.8 \cdot 4+0.6 \cdot 16+0.9 \cdot 4) \cdot 365=5986,
$$

and power unregulated $\mathrm{CD}$, MVAR

$$
Q_{C}=\frac{5986}{8760}=0.6833 .
$$

With such a power of unregulated CD, the amount of energy consumed per year will decrease and make up (MVARh)

$$
W Q_{\text {cons }}=((0.8-0.683) \cdot 4+(0.9-0.683) \cdot 4) \cdot 365=486.7 \text {, }
$$

and the generation of reactive energy into the network (MVARh)

$$
W Q_{\text {gen }}=((0.6-0.6833) \cdot 16) \cdot 365=-486.7 .
$$

The mode of partial recombination of reactive power in order to reduce electricity losses can be allowed in electric networks of power supply companies provided that the voltage deviations are allowed. As for the compensation of reactive load of consumers, when choosing the optimal power of unregulated $\mathrm{CD}$, we should also take into account the payment for the flow of reactive electricity between the energy supplying organization and its customers [16].

The general criterion for optimizing the reactive power mode is the minimum of discounted costs [17]

$$
C_{d c}=\frac{C_{e}+C_{\text {loss }}+C_{Q}}{E}+K,
$$

where $C_{e}$ is maintenance and repair costs for the $\mathrm{CD} ; C_{\text {loss }}$ is the cost of electricity losses in the electricity network; $C_{Q}$ is charge for the flow of reactive electricity; $K$ is capital investments for the establishment of a CD; $E$ is discount rate, which takes into account depreciation due to inflation.

The optimal power of the CD can be determined by minimizing the target function (5), in which the cost of losses in the 
electrical network is taken into account depending on the full load power, while the partial criterion of the minimum total energy losses can take into account only the component of losses from the transfer of reactive power, as the component of losses from transmission of active power practically remains constant. The minimum total power losses correspond to the minimum loss of reactive power transmission.

It is necessary to consider that in the modes of minimum loads in case of unregulated $\mathrm{CD}$, unacceptable excess voltage overhead in the nodes of the electrical network is possible, therefore, at the same time, it is necessary to control the voltage levels in these nodes.

In general, the problem of choosing the optimal power of a $\mathrm{CD}$ by criterion (5) needs to be solved with allowance for technical constraints

$$
\begin{gathered}
0 \leq Q_{C} \leq Q_{n}^{\max } ; \\
U_{\min } \leq U_{i} \leq U_{\max } ; \\
I_{i} \leq I_{i \max } .
\end{gathered}
$$

Let us analyze the efficiency of compensation of reactive load power. We establish the dependence of the losses of active power in the electric network on the power factor $\cos \varphi$, expressing them as

$$
\Delta P=\frac{S^{2}}{U^{2}} r=\frac{P^{2}}{U^{2} \cos ^{2} \varphi} r .
$$

As we see from (6), the loss of active power in the network depends inversely quadratically on the power factor.

In case of active load $(\cos \varphi=1)$ active power loss will be minimal

$$
\Delta P_{\min }=\frac{P^{2}}{U^{2}} r
$$

In case of an actively-inductive nature of the network load on it, in addition to the active, reactive power is transmitted. At the same time, the power factor decreases and power losses increase. For example, in case of $\cos \varphi=0.85$ an increase in power losses will be

$$
\delta=\frac{\Delta P}{\Delta P_{\min }}=\frac{1}{0.85^{2}}=1.38,
$$

that is, compared with the transfer of only active power, the relative increase in losses in this case will be (\%)

$$
\delta P=\frac{\Delta P-\Delta P_{\min }}{\Delta P_{\min }} 100=38 .
$$

Table 4 shows the results of calculating the growth and relative increase in power losses in the network depending on the load factor.

Fig. 4 shows the graphical dependence of the relative increase in power loss on the power factor.

Table 4

The results of calculating the relative increase in active power losses depending on the power factor

\begin{tabular}{|l|c|c|c|c|c|c|c|c|c|}
\hline $\begin{array}{l}\text { Power } \\
\text { factor cos } \varphi\end{array}$ & 1 & 0.95 & 0.9 & 0.85 & 0.8 & 0.75 & 0.7 & 0.65 & 0.6 \\
\hline $\begin{array}{l}\text { Relative } \\
\text { growth of } \\
\text { losses } \delta\end{array}$ & 1 & 1.08 & 1.23 & 1.38 & 1.56 & 1.78 & 2.04 & 2.37 & 2.78 \\
\hline $\begin{array}{l}\text { Relative } \\
\text { increase in } \\
\text { losses } \delta P, \%\end{array}$ & 0 & 10.8 & 23 & 38 & 56 & 78 & 104 & 137 & 178 \\
\hline
\end{tabular}

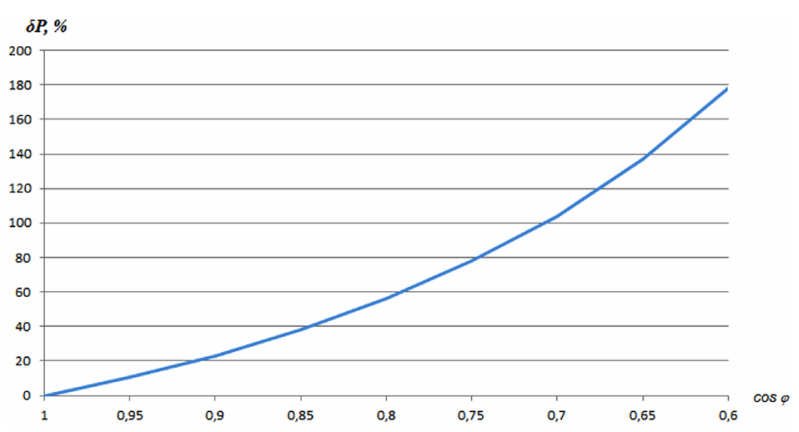

Fig. 4. Graph of the relative increase in active power losses from the load factor

As we see from the calculations, the efficiency of increasing the load factor to reduce power losses is brought down, especially at high $\cos \varphi$ values. For example, in case of growing of $\cos \varphi$ from 0.7 to 0.8 , the power loss is reduced by $48 \%$, and from 0.8 to 0.9 - only by $33 \%$.

Let us evaluate the efficiency of transverse compensation of the reactive load by analyzing the change in the active power losses in the power line from the reactive power transfer at different levels of its compensation.

The loss of active power in the line from reactive power transmission $Q$ over time $t$ in the absence of compensation is

$$
\Delta W_{r}=\frac{Q^{2}}{U_{n o m}^{2}} r t,
$$

where $U_{\text {nom }}$ is rated line voltage; $r$ is active line resistance.

The loss of active power in the line in the presence of compensation depends on the magnitude of the power compensating devices $Q_{C}$, switched on in parallel with the load,

$$
\Delta W_{C}=\frac{\left(Q-Q_{C}\right)^{2}}{U_{n o m}^{2}} r t .
$$

The relative amount of electricity losses will be

$$
\gamma=\frac{\Delta W_{C}}{\Delta W_{r}}=\frac{\left(Q-Q_{C}\right)^{2}}{Q^{2}},
$$

and the relative reduction of electricity losses from reactive power transmission, expressed as a percentage,

$$
\begin{gathered}
\delta W_{r} \%=\frac{\Delta W_{r}-\Delta W_{C}}{\Delta W_{r}} 100= \\
=\left(1-\frac{\Delta W_{C}}{\Delta W_{r}}\right) \cdot 100=\left(1-\frac{\left(Q-Q_{C}\right)^{2}}{Q^{2}}\right) \cdot 100 .
\end{gathered}
$$

For example, for partial compensation of reactive power $Q_{C}=0.25 Q$, the relative reduction of losses will be

$$
\delta W_{r} \%=\left(1-\frac{(Q-0.25 Q)^{2}}{Q^{2}}\right) \cdot 100=43.75 .
$$

Similarly, the loss of active (similarly, reactive) electricity for other values of $Q_{C}$ can be determined, and with full compensation of the reactive load $Q_{C}=Q$ and $\delta W_{r}=100 \%$. The calculation results are given in Table 5 .

Fig. 5 depicts the dependence of the relative reduction of electricity losses on the level of reactive power compensation (RPC).

As can be seen from Fig. 5, with the RPC level increasing, the amount of energy savings initially grows up rapidly, after that the relative increase in electricity savings begins to reduce. 
Table 5

Relative energy savings for different levels of reactive load compensation

\begin{tabular}{|c|c|c|c|c|}
\hline $\begin{array}{c}\text { Level of } \\
\text { compensation, } \\
\%\end{array}$ & $Q_{C}$ & $Q_{C}, \%$ & $\begin{array}{c}\gamma, \\
\text { relative } \\
\text { units }\end{array}$ & $\delta W_{r}, \%$ \\
\hline 0 & 0 & 0 & 1 & 0 \\
\hline 25 & $0.25 Q$ & 25 & 0.563 & 43.7 \\
\hline 50 & $0.5 Q$ & 50 & 0.25 & 75 \\
\hline 75 & $0.75 Q$ & 75 & 0.0625 & 93 \\
\hline 100 & $Q$ & 100 & 0 & 100 \\
\hline
\end{tabular}

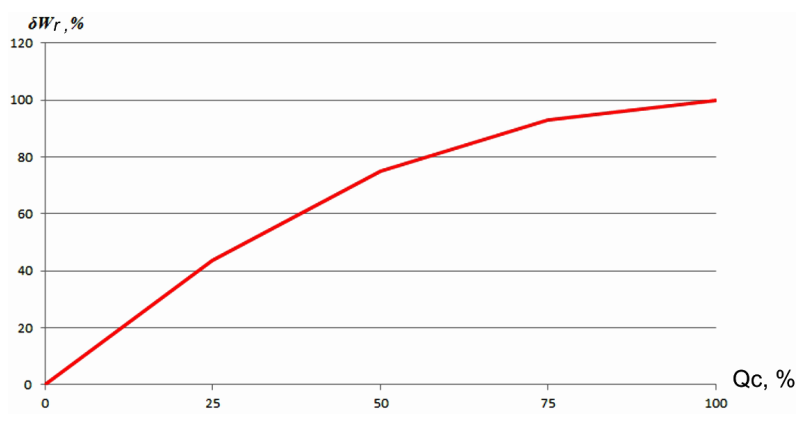

Fig. 5. Dependence of electricity saving on the level of compensation of reactive load power

For example, with an increase in power $Q_{C}$ from zero to $50 \%$ the power loss in the line from the reactive power transfer has lowered at $75 \%$ and with a further rising of $Q_{C}$ from 50 to $100 \%$ only by $25 \%$.

Consequently, the compensation efficiency due to the power factor increasing is significantly reduced, therefore, the optimal power of the CD should be selected on the basis of feasibility study taking into account the cost of electricity losses, capital investments and payments for the electricity flow between the transmission company and its customers [4, 5].

\section{Conclusions.}

1. The analysis of electric power loss calculation errors is carried out by the approximate method accourding to the largest loss time, which is given by the constant value depending on the time of using the largest load.

2. It is shown that the error of calculation of losses by the approximate method depends on the configuration of the graphs and the duration of active and reactive loads. The absolute value and the error sign depend on the ratio and magnitude of these loads.

3. The dependence of electric power losses and time of the greatest losses on the power of compensating devices is analyzed. Failure to take into account the change in the time of the greatest losses from the change in the schedule of reactive loading leads to significant errors during the feasibility study.

4. It is shown that in the case of reactive load compensation, the electric power loss calculation error by the approximate method decreases as a result of reducing the effect of this load on the magnitude of complex power, while the time of the largest losses decreases and reaches the minimum value for the compensation power that corresponds to the minimum power losses.

5. In case of using the unregulated compensating devices, the minimum power losses correspond to the condition of the equality of the amount of consumed electricity during the calculation period and generated electricity in the system during the overcompensation. In this case, the power of unregulated compensating devices is equal to the average reactive power of the load during this period, which can be determined by the readings of the measuring devices.
6. The mode of partial overcompensation of the load reactive power in order to reduce the losses of electric energy can be allowed in electric networks of power supply companies in the conditions of providing the permissible levels of voltage in the nodes of the electrical network. The general criterion of optimization is the minimum of discounted costs for installing compensating devices and their operation taking into account the cost of electricity losses and payments for the reactive electricity flow between the transmission company and its customers.

7. The analysis showed that with the power factor increasing, the relative efficiency of compensation is reduced, so the optimal power of compensating devices must be determined by minimizing the function of discounted costs. In the analysis, the generated power can be considered conditionally as the load capacity of the line with a positive sign and the power losses should be determined regarding the time of the greatest losses.

8. In order to increase the accuracy of electricity loss calculations in power supply systems, it is recommended to determine graphical integration according to the data of modern information systems of electricity accounting.

\section{References.}

1. CIRED: Working Group CC-2015-2 on losses reduction. (2017). Reduction of Technical and Non-Technical Losses in Distribution Networks. Final report 2017. Retrieved from http:// www.cired.net/files/download/188.

2. Zhelezko, Yu.S. (2016). Electricity loss. Reactive power. Electric power quality: a guide for practical calculations. Moscow: ENAS.

3. Tsyplenkov, D.V., \& Krasovs'kyy, P.Y. (2015). Methods and means of technical losses reduction of electricity in the elements of power supply systems. Elektrotekhnika ta elektroenerhetyka, (1), 77-82.

4. Gracheva, E. I., Ilyasov, I. I., \& Alimova, A. N. (2018). The comparative analysis and research of methods of calculation of losses of the electric power in the systems of electrical power supply of the industrial enterprises. Power engineering: research, equipment, technology, 20(3-4), 62-71. DOI: 10.30724/ 1998-9903-2018-20-3-4-62-71.

5. Romaniuk, Y. F., \& Solomchak, O. V. (2019). Application of the method of Lagrange's undetermined multipliers in determination of optimal reactive power compensation. The current stage of development of scientific and technological progress' 2019, SWorld. Retrieved from https://www.sworld.com.ua/ index.php/ru/ge7-5/31224-ge7-030.

6. Solomchak, O. V., \& Solomchak, A. O. (2017). The choice of the optimal variant of compensation of reactive power at the $35 / 10 \mathrm{kV}$ district substation, which feeds the trunk line. International scientific and technical journal "Modern problems of electric power engineering and automation”, 192-195. Retrieved from http://jour.fea.kpi.ua/article/download/130406/126028. 7. Kulyk, V., Burykin, O., \& Pirniak, V. (2018). Comprehensive evaluation of the effectiveness of installing the reactive power sourcies in distribution electric grids. Visnyk Kyyivskoho Natsionalnoho Universytetu Tekhnolohii ta Dyzainu. Seriya Tekhnichni Nauky, 4(124), 103-111. DOI:10.30857/18136796.2018.4.11.

8. Khomenko, I. V., Piskuriov, M. F., \& Stasiuk, I. V. (2018). On the issue of compensation of reactive power in electric systems. Bulletin of the National Technical University "KhPI". Ser.: Problems of electrical machines and apparatus perfection. Theory and practice, 32(1308), 71-76.

9. Kulyk, V. V., \& Pirnyak, V. M. (2017). Optimization of the flow of reactive energy in the distribution electrical networks using the principle of least action. Visnyk Vinnytskoho Politekhnichnoho Instytutu, (6), 71-79.

10. Demov, O.D., Nykytenko, Y.V., \& Konoplytskyi, V.A. (2015). Influence of the compensating installations of industrial consumers on decrease in losses in distributive networks 
of the power supplying companies. Visnyk Vinnytskoho Politekhnichnoho Instytutu, (6), 125-128.

11. Demov, O.D. (2016). Optimization of the implementation process of compensating installations in distributive electrical networks of energy supply companies: monograph. Vinnytsia: VNTU.

12. Lezhnyuk, P. D., \& Nanaka, O. M. (2015). Developing conditions for optimality of reactive power compensation in electrical networks of consumers and energy supply companies. Vinnytsia: VNTU.

13. Stanev, R. (2014). Estimation of the impact of distributed energy resources on electrical network power losses. In Electrical Apparatus and Technologies (SIELA) 2014, $18^{\text {th }}$ International Symposium (pp. 1-4). DOI: 10.1109/SIELA.2014.6871890.

14. Glover, J.D. (2016). Power system analysis and design. SI Edition. (6 ${ }^{\text {th }}$ ed.). Kindle Edition: Cengage Learning. ISBN: 978-1305636187.

15. Iqteit, N., Basa Arsoy, A., \& Çakır, B. (2018). Load Profile-Based Power Loss Estimation for Distribution Networks. Electrica, 18(2), 275-283.

16. Ministry of Fuel and Energy of Ukraine (2018). Method for calculating the payment for the reactive power flow between the transmitting company and its customers. Kyiv: Ministry of Fuel and Energy of Ukraine. Retrieved from https://zakon.rada. gov.ua/laws/show/z0392-18.

17. Ministry of Energy of Ukraine (2017). Determination of the economic efficiency of capital investments in the energy sector. The technique. Power systems and electric networks: GKD340.000.002-97. Kyiv: Ministry of Energy of Ukraine.

\section{Особливості розрахунку втрат електроенергії в електропостачальних системах 3 компенсувальними пристроями}

\section{Ю. Ф. Романюк, О. В. Соломчак, П. М. Николин, У. М. Николин}

Івано-Франківський національний технічний університет нафти і газу, м. Івано-Франківськ, Україна, е-mail: ulanda@gmail.com

Мета. Підвищення точності розрахунку втрат електроенергії в системах електропостачання нафтогазового комплексу з компенсацією реактивної потужності навантаження шляхом застосування методу графічного інтегрування втрат потужності та вибір оптимальної потужності компенсувальних пристроїв.

Методика. Удосконалена методика визначення часу найбільших втрат з урахуванням найбільших втрат потужності окремо від передачі активної й реактивної потужностей дала змогу підвищити точність визначення втрат електроенергії. Запропонована методика визначення оптимальної потужності компенсувальних пристроїв.

Результати. Обгрунтована необхідність урахування форми графіків активної й реактивної потужностей та потужності компенсувальних пристроїв під час розрахунку втрат електроенергії в системах електропостачання. Показано, що ефективність компенсації реактивної потужності з метою зменшення втрат електроенергії суттєво знижується за високих значень коефіцієнта потужності.

Наукова новизна. Запропонована методика розрахунку оптимальної потужності нерегульованих компенсувальних пристроїв за умови забезпечення мінімальних втрат потужності в електропостачальній системі. Удосконалено метод розрахунку втрат електроенергії в системах електропостачання з компенсувальними пристроями шляхом окремого врахування активної й реактивної складових потужності під час визначення часу найбіль- ших втрат, що дозволяє підвищити точність і зменшити похибки розрахунків. Синтезована структура методу визначення втрат електроенергії в мережі, що, на відміну від існуючих, дає змогу врахувати вплив різночасності максимумів активного й реактивного навантаження на точність розрахунків і оптимізувати потужність компенсувальних пристроїв.

Практична значимість. Підвищення точності розрахунку втрат електроенергії. Вибір оптимальної потужності нерегульованих компенсувальних пристроїв, що відповідає мінімуму втрат потужності в мережі живлення.

Ключові слова: втрати електроенергії, компенсувальний пристрій, ефективність компенсації

\section{Особенности расчета потерь электроэнергии в системах электроснабжения с компенсирующими устройствами}

\author{
Ю. Ф. Романюк, О. В. Соломчак, П. М. Николин, \\ У. М. Николин
}

Ивано-Франковский национальный технический университет нефти и газа, г. Ивано-Франковск, Украина, e-mail: ulanda@gmail.com

Цель. Повышение точности расчета потерь электроэнергии в системах электроснабжения нефтегазового комплекса с компенсацией реактивной мощности нагрузки путем применения метода графического интегрирования потерь мощности и выбор оптимальной мощности компенсирующих устройств.

Методика. Усовершенствованная методика определения времени наибольших потерь с учетом наибольших потерь мощности отдельно от передачи активной и реактивной мощностей позволила повысить точность определения потерь электроэнергии. Предложена методика определения оптимальной мощности компенсирующих устройств.

Результаты. Обоснована необходимость учета формы графиков активной и реактивной мощностей и мощности компенсирующих устройств при расчете потерь электроэнергии в системах электроснабжения. Показано, что эффективность компенсации реактивной мощности с целью уменьшения потерь электроэнергии существенно снижается при высоких значениях коэффициента мощности.

Научная новизна. Предложена методика расчета оптимальной мощности нерегулируемых компенсирующих устройств при условии обеспечения минимальных потерь мощности в электроснабжающей системе. Усовершенствован метод расчета потерь электроэнергии в системах электроснабжения с компенсирующими устройствами путем отдельного учета активной и реактивной составляющих мощности при определении времени наибольших потерь, что позволяет повысить точность и уменьшить погрешности расчетов. Синтезирована структура метода определения потерь электроэнергии в сети, которая, в отличие от существующих, позволяет учесть влияние разновременности максимумов активной и реактивной нагрузки на точность расчетов и оптимизировать мощность компенсирующих устройств.

Практическая значимость. Повышение точности расчета потерь электроэнергии. Выбор оптимальной мощности нерегулируемых компенсирующих устройств, которая соответствует минимуму потерь мощности в сети.

Ключевые слова: потери электроэнергии, компенсирующее устройство, эффективность компенсации

Рекомендовано до публікації докт. техн. наук М. Й. Бурбело. Дата надходження рукопису 21.11.18. 